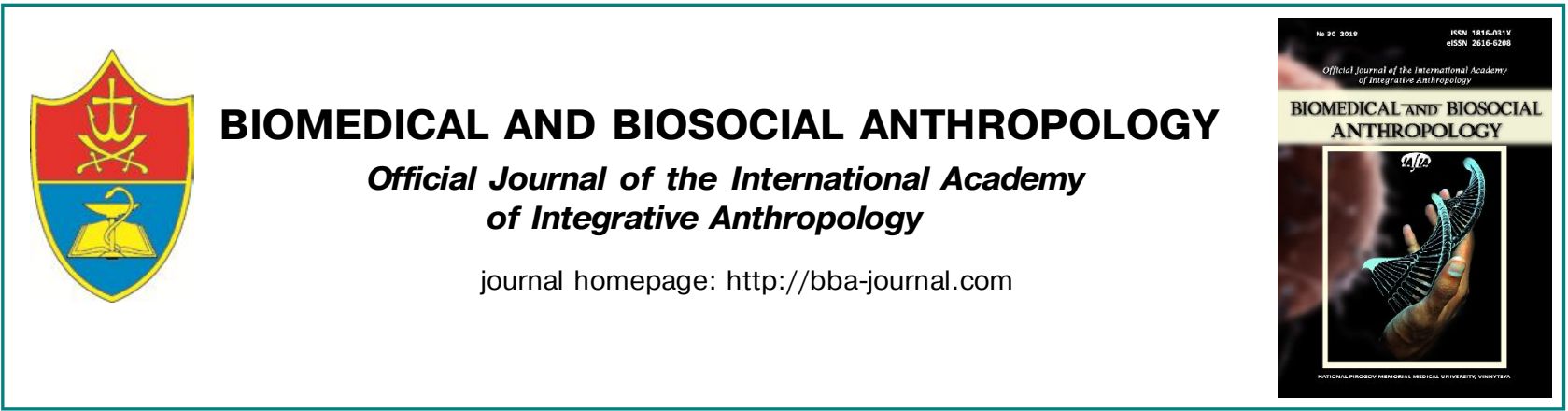

\title{
The most pronounced constitutional differences between healthy and sick with pyoderma in men or women in the western region of Ukraine
}

\author{
Mateshuk-Vatseba L.R., Chaplyk-Chyzho I.O.
}

Danylo Halytsky Lviv National Medical University, Lviv, Ukraine

\author{
ARTICLE INFO \\ Received: 12 December, 2017 \\ Accepted: 22 January, 2018 \\ UDC: $611.01: 616.5-$ \\ 002.3:572.511.3]-071.2(477.8)
}

\section{CORRESPONDING AUTOR}

e-mail: chch20.iryna@gmail.com

Chaplyk-Chyzho I.O.
Despite the significant progress made in the study of the problem of pyoderma, the clinical features of their course depending on the somatotype and their differences, as compared with the healthy subjects, remain virtually unexplored. The purpose of the study is to establish the most pronounced discrepancies between the anthropometric, somatotypological and component components of body mass in men and women of the Western region of Ukraine in norm and in patients with pyoderma. An anthropological examination under the Bunak scheme of 45 patients with pyoderma men aged from 22 to 35 years, and 48 patients with pyoderma women aged from 21 to 35 years, and 24 healthy men and 43 healthy women of similar age, the third generation residents of the West region of Ukraine was conducted. The somatotype is defined according to the mathematical scheme of the Hit-Carter. For the calculation of the fat, bone and muscle mass components of the body, Matiegka and the American Institute of Nutrition formulas were used. With the help of the license package "STATISTICA 6.0", the statistical processing of the obtained results was performed using parametric and non-parametric estimation methods. In healthy men, lower values of the thickness of skin and fat folds are found, than in patients with acute and chronic pyoderma; as well as lower values of the endo- and mesomorphic components of the somatotype and the fatty component of the body mass and the higher values of the ectomorphic component of the somatotype than in the patients with the acute course of the disease; a lower percentage of endomesomorphic somatotype representatives than in patients with deep pyoderma. In healthy women found smaller than in female patients of different groups of the majority of total, cross, girth body size, width of distal epiphysis of long bones of the extremities and mesomorphic somatotype component, muscle and bone components of body weight, and higher values ectomorphic somatotype component; a smaller percentage of the mesomorphic somatotype than those of the general group and with the acute course of pyoderma, as well as a higher percentage of the representatives of the ectomorphic somatotype than patients with superficial pyoderma. In patients with chronic pyoderma men set lower than in patients with acute pyoderma men, meaning of cross medium and lower thoracic sizes, thickness of skin-fat folds, endo- and mesomorphic somatotype components and bone and fat components of body weight. In patients with chronic pyoderma women set less than women suffering from deep pyoderma, the value of total, half of the transverse dimensions of the pelvis, extremities, most girth sizes, width of distal epiphysis of the shoulder and hip, muscle and bone components of body weight and a higher percentage representatives of the ectomorphic somatotype than patients with superficial pyoderma. Comparative study of anthropometric indices and individual somatic sex groups and constitutional types showed individual variability of body structure and set typological features of patients with some form and degree of manifestation of pyoderma.

Keywords: anthropometry, somatotype, component mass of the body, practically healthy men and women of the Western region, patients with pyoderma. 


\section{Introduction}

As you know, purely dermatological diseases do not exist. Under the pronounced reaction of the skin lies the disruption of the liver, kidneys, as well as the lymphatic and immune systems [18]. Therefore, the examination for skin diseases should consist of a carefully selected list of analyzes and a survey of doctors of another specialization, which are designed not only to identify skin diseases (often it can be done with the naked eye), but to identify the true causes of all disorders in the body $[1,28]$.

Most scholars tend to believe that dermatological diseases have a multifactorial nature and genetic factors may be the basis for structural and functional changes characteristic of them [14, 21]. However, until now, this question remains practically not studied to the proper extent. This circumstance, as well as the complexity and high cost of genetic research, determines the relevance of the search for more available genetic predisposition markers to the formation of these nosologies, which would meet the following criteria: 1) the integral nature of the marker and its stability; 2) the simplicity and accessibility of the research methodology, which does not require expensive equipment, reagents and highly skilled personnel; 3) the non-invasiveness of the examination procedure and its non-severity for the patient. These requirements are met by anthropometric and somatotypological research methods. After all, the morphophenotype of the constitution is the most available for research, relatively stable in ontogenesis and genetically deterministic characteristic of the integrity of an organism [13, 21].

Anthropological approach in assessing the state of health and the propensity to a certain pathology has repeatedly substantiated its scientific and practical importance. The application of anthropometric methods allows us to study the biological features of the organism of the subject under investigation, to estimate, predict the peculiarities of the course of many diseases, and to form a risk group for them purposefully $[13,29]$.

The team of researchers [14] studied the morphofunctional features of the skin and established dermatological diseases that are inherent in certain constitutional types in young people and older age groups. Thus, the skin in ectomorphs is cold to the touch, dull, dehydrated and dry, there is a tendency to vascular spasm. Typical hyperkeratosis caused by a decrease in the proliferative activity of cells of the epidermis. Weakly structured keratin does not provide full protection of the skin from aggressive environmental influences. Therefore, the skin of ectomorphs is characterized by high reactivity and a tendency to develop hypersensitivity and allergic reactions. In endomorphs, the skin is mild, but not flabby, as in ectomorphs, and not elastic, as in mesomorphs. The derma is quite advanced, often thickened due to fluid retention due to the constitutional weakness of the microcirculation. There is a tendency to stable expansion of the capillaries and microvessels of the venous bed. This explains the tendency of endomorphs to develop rosacea. The skin of endomorphs takes an active part in the elimination of toxins.
Due to this, it becomes denser, the level of its $\mathrm{pH}$ changes, which creates favorable conditions for the development of pathogenic microflora and, in fact, the propensity to develop acne and mycoses. Endomorphs, as a rule, suffer from damp eczema, warts, herpes, comedones, acne and post acne. The mesomorphic skin is characterized by a thick epidermis and dermis, prone to seborrhea and the development of hyperpigmentation and nevus.

The revealed regularities of clinical manifestations in dermatologic patients, depending on the somatotype, give the right to recommend the application of anthropometric and somatotypological methods in dermatological practice. The combination of standard diagnostic methods with anthropometry allows predicting the characteristics of the course of skin diseases in individuals of different somatotypes [10].

Pyoderma is the most common skin disease that manifests itself in individuals 12-30 years old and older. Dermatosis remains an important clinical problem due to its widespread, recurrent course, the growth of severe forms, high specific gravity of patients requiring inpatient treatment $[6,33]$.

The features of the skin structure and a large number of external and internal factors affecting it, determine the variety of forms of this pathology of the skin. The disease often takes a chronic and recurrent course, which requires persistent, long-term therapy, which does not always lead to the desired result $[22,27]$.

To reduce the growth of morbidity for various forms and types of the course of pyoderma requires active prognostic and preventive work, which is possible only with a detailed study of the structural features of healthy and patients in the course of screening with subsequent identification of risk groups for the onset of dermatosis [9]. Perspective is the combination of the aforementioned diagnostic complex with anthropo-somatotypological research, in fact, with the study of basic morphological parameters and the variability of body components $[7,15]$.

Despite the significant progress made in the study of the problem of pyoderma, the clinical features of their course depending on the somatotype and their differences, as compared with the healthy subjects, remain virtually unexplored. This leads to the need to study these relationships in the perspective of future research, which, in turn, will enable to predict the development of various clinical forms of pyoderma, as well as assess the effectiveness of the therapy.

The aim of the study was to establish the most pronounced differences of anthropometric, somatotypological and indices of the body mass composition in men and women of the Western region of Ukraine in norm and in patients with pyoderma.

\section{Materials and methods}

The subject of clinical and anthropological examination were 45 patients with pyoderma men in the age from 22 
to 35 years old, and 48 patients with pyoderma women aged from 21 to 35 years, as well as 24 practically healthy men and 43 healthy women of similar age, in the third generation residents of the Western region of Ukraine.

According to the Bunak scheme, an anthropometric survey [3] was carried out. The evaluation of the somatotype was carried out according to the mathematical scheme of the Hit-Carter [4]. Matiegka and the American Institute of Nutrition [11, 19] have been used to calculate the fat, bone and muscle mass components of the body.

With the help of the license package "STATISTICA $6.0 "$, the statistical processing of the obtained results was performed using parametric and non-parametric estimation methods. Evaluated the correctness of the distribution of attributes according to each variation series, average values for each, their deviations and standard errors. The reliability of the difference in values between independent quantitative values in normal distribution was determined by Student's criterion, and in other cases by the Man-Whitney U-criterion.

\section{Results}

In analyzing the differences between constitutional parameters of the body between healthy and sick men, in most cases, healthy men have lower values of the thickness of skin and fat folds than in patients with acute $(24,9 \% \downarrow)$ and chronic pyoderma $(1,7 \% \downarrow)$. In addition, in healthy men, lower values of the endo- $(20,6$ $21,8 \% \downarrow)$ and mesomorphic $(14,6-14,4 \% \downarrow)$ components of the somatotype and fat component of

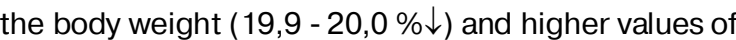
the ectomorphic component of the somatotype $(23,2$ $-25,9 \% \uparrow$ ) than in patients with acute course (Fig. 1) have been set. Also, in healthy men, a lower percentage of endo-mesomorphic somatotype $(14,1 \%)$ was found in patients with deep pyoderma (40,0\%) (see Fig. 1).

In healthy women, in most cases, lower than in patients of general group women, patients with acute pyoderma and, separately, on superficial and deep dermatosis, the values of most total $(4,5-6,1-4,2-9,3 \% \downarrow)$, transverse $(0,2-0,4-2,5-2,8 \% \downarrow)$, girth $(6,3-8,8-7,6-10,7 \% \downarrow)$ body sizes, width distal epiphyses of long limb bones $(4,4$ $5,6-4,9-6,6 \% \downarrow)$, as well as mesomorphic component of somatotype $(21,6-25,3-21,7-30,7 \% \downarrow)$, muscle $(11,2$ $14,6-12,0-18,4 \% \downarrow)$ and bone $(6,2-29,5-5,8-12,4 \%$ $\downarrow$ ) body mass components, as well as higher value of ectomorphic component of the somatotype (24,6 - 27,7 $24,1-33,5 \%$ 个) (Fig. 2). In addition, in healthy women, a smaller percentage of the mesomorphic somatotype (34,8\%) was found, than in patients of the general group $(54,2 \%)$ and with acute pyoderma $(51,4 \%)$; as well as a higher percentage of the representatives of the ectomorphic somatotype (20,0\%) than patients with superficial pyoderma (4,3\%) (see Fig. 2 ).

In analyzing the differences in the constitutional parameters of the body between sick men, in most cases, in

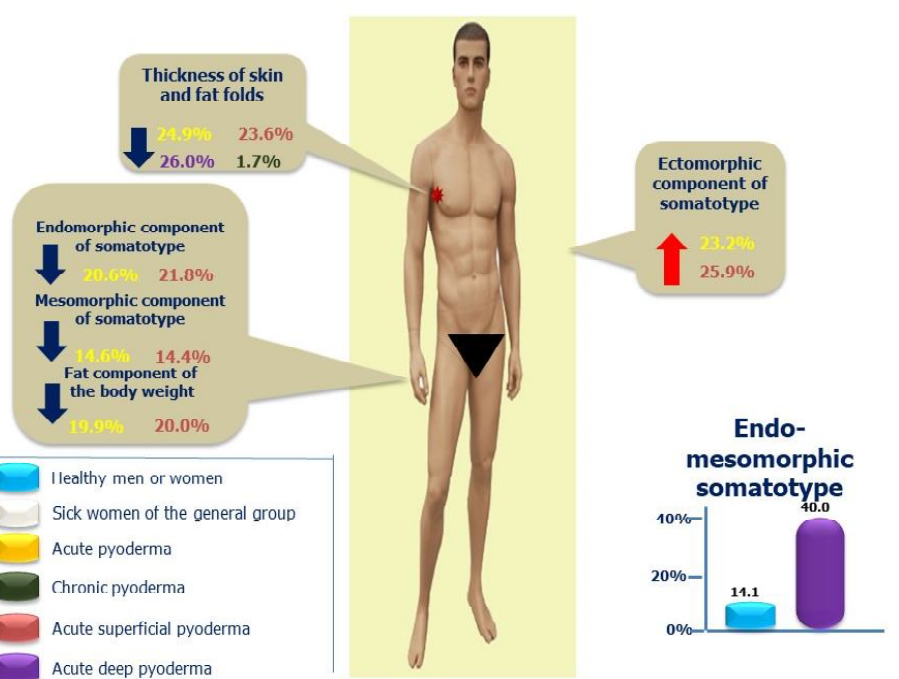

Fig. 1. Differences of constitutional indicators between practically healthy and patients with pyoderma in men of the Western region of Ukraine.

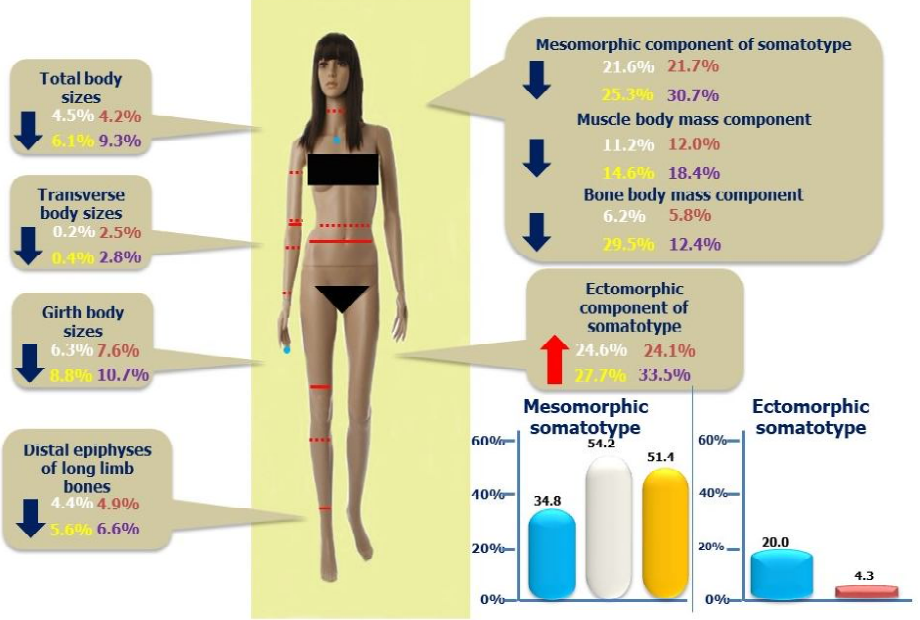

Fig. 2. Differences of constitutional indicators between practically healthy and sick with pyoderma among women of the Western region of Ukraine.

patients with chronic pyoderma, were found lower values than those with acute pyodermic patients, transverse values of middle- $(4,9-4,05-5,5 \% \downarrow)$ and lower breast size $(6,2$ $4,9-7,3 \% \downarrow)$, thickness of skin and fat folds (23,6 - 22,3 $24,7 \% \downarrow)$, endo- (25,2 - 26,3 - 24,3\% $\downarrow$ ) and mesomorphic $(16,8-16,5-16,9 \% \downarrow)$ components of somatotype and bone $(11,3-10,8-11,7 \% \downarrow)$ and fatty $(28,0-28,1-27,9 \%$ $\downarrow$ ) components of the body mass (Fig. 3).

In patients with chronic pyoderma women, in most cases, fewer than in women with deep pyoderma, the values of total $(10,6 \% \downarrow)$, half of transverse pelvis $(6,9 \% \downarrow)$, most of the circumflex size of the limbs $(13,6 \% \downarrow)$, width of the distal shoulder epiphyses $(6,4 \% \downarrow)$ and thighs $(8,3 \% \downarrow)$, muscle $(20,25 \% \downarrow)$ and bone $(14,1 \% \downarrow)$ body mass (Fig. 4 ) found. In addition, patients with chronic pyoderma in women have a higher percentage of ectomorphic somatotype $(27,3 \%)$ than patients with superficial pyoderma (4,3\%) (see Fig. 4).

\section{Discussion}




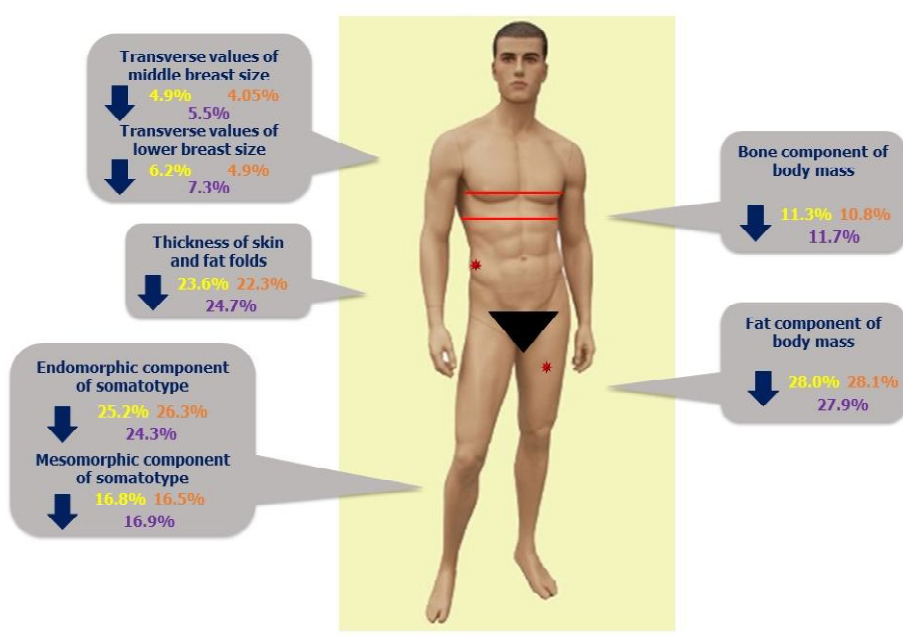

Fig. 3. Differences in constitutional indicators between patients with pyoderma men in the Western region of Ukraine.

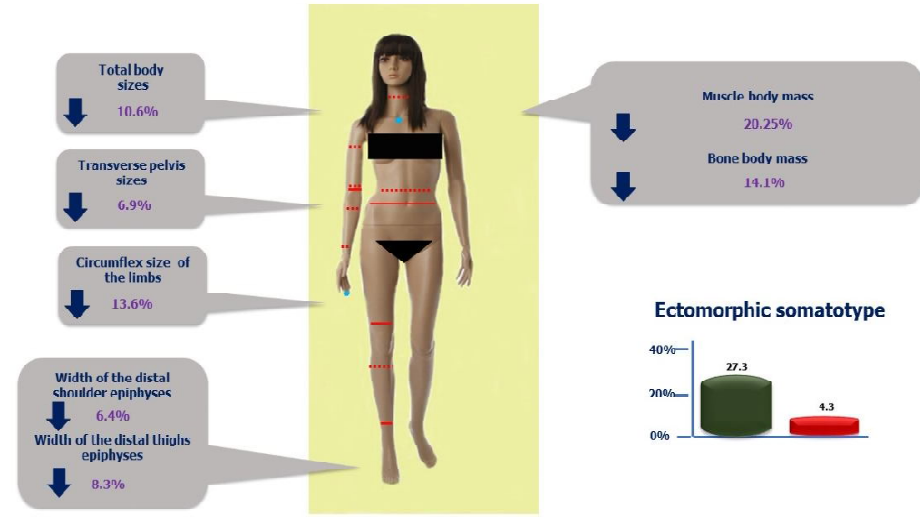

Fig. 4. Differences between constitutional indicators among women with pyoderma in the Western region of Ukraine.

Some of scientists, in a group comparison of dimensional, circumferential and transverse parameters of the body of the subjects of both sexes examined, that at the same length of the body patients with pyoderma $[5,16,17]$ have a greater value of these indicators than healthy peers. In the female sample, we obtained similar results; in men, the differences between these groups of sizes are practically not established.

It is proved that determining the thickness of skin and fat folds in 4 places (on the shoulder, side, hip, abdomen) is most significant and allows obtaining information about localization, the degree of deposition of fat in different parts of the body, and thus determine the type of obesity as a risk factor for development many multifactorial diseases [30]. Scientific studies have shown that fat deposits can protect the human body from adverse effects of diabetes, insulin resistance, decreased estrogen levels, and general intoxication $[2,8]$.

Therefore, it is quite logical to obtain larger values of the thickness of skin and fat folds in patients studied compared with healthy ones. Thus, we have established significantly higher values of the thickness of skin and fat folds on the posterior, anterior surface of the shoulder and on the side of the patients with pyoderma of men, revealing respectively the metabolic (exchange) and neurodyshormonal nature of this pathology.

Between healthy and patients with pyoderma, women have not found any reliable or trend differences in the thickness of all skin and fat folds. This is probably due to the fact that the process of excess fat removal in women is physiologically associated with periods of puberty, menarche, pregnancy, lactation, and menopause. Greater adaptability of women to external and internal stressors allows to "smooth out" the difference of this anthropometric indicator in patients and healthy subjects of female sex $[2,12,20]$.

Objective characteristic of the body composition are calculations of the components of body weight: fatty, muscular and bone. It should be noted that the data on the component body composition are included in the assessment of constitutional types and serve as objective indicators of intergroup differences [24, 25, 26].

An increase in fat mass in adults is associated with an increase in morbidity, precise quantitative and topical diagnosis of excess fat intake should be performed to determine the risk of the development of diseases associated with obesity. According to various authors, the highest frequencies of the maximum risk of inflammatory diseases of the skin are characterized by somatotypes with significant development of the fatty component or fat and muscle tissue at the same time: picnic type or abdominal muscle and muscleabdominal variants. A connection was found not only with the degree but also with the topography of hypodermic fatty tissue [14, 31].

Like, both men and women have pronounced differences in body mass components and somatotype components - in healthy subjects of both sexes, their lower values are, in addition to the magnitude of the ectomorphic component of the somatotype.

It is proved that in patients with chronic pyoderma, there is an imbalance of specific and non-specific immunological reactions of the organism with the phenomena of dysproteinemia, an increase in the number of monocytes and neutrophils. Chronic and decompensated forms of dermatitis are one of the causes of disorders of the activity of the glands of the internal secretion responsible for growth and development [23, 32].

The most likely explanation of the lower values of anthropometric indices in patients with chronic pyoderma is the depletion of the tissue substrate, the construction of which requires a large number of its constituent parts. In the body there is a deficiency of enzymes, hormones, proteins, fats, carbohydrates and, as a consequence, inhibition of growth and development in this category of patients [34]. Our data suggest that the minimum mean values of the above described parameters are recorded in the group of patients with chronic pyoderma flow compared with patients with a different form and the course of dermatosis. 
Constitutional affiliation defines the limits of the individual variability of the adaptive reactions of the body of patients with dermatoses to the environment. Work on the peculiarities of the course of skin diseases in patients with different types of constitution $[5,10,14,16,21]$ show that the prevalence in a population of varying degrees and form of manifestation on the body of the pyoderma has a certain dependence on the human body structure. In the case of comparing the percentage of identified constitutions between patients with different forms of pyoderma, variants of the duration and form of the disease are predicted, and when we compare healthy and sick with dermatoses, we obtain the criterion of the "risk" of its phenotypic manifestation.

According to the data of the dissertation research Ya.O. Hendogina [5], life-time contact biomicroscopy of the skin revealed that the manifestations of acne were 2 times more common in muscular, abdominal and indeterminate somatotypes than in the representatives of the thoracic. A. M. Layton and I.M. Makarchuk $[12,16,17]$ identified different types of body structures in healthy subjects and patients with initial and severe acne severity.

Similarly to the results of these studies, we obtained differences in percentages of representatives of different somatotypes as compared to healthy patients with pyoderma, and between patients with different forms and the course of dermatosis.

It is obvious that it is necessary to apply in practice approaches that take into account peculiarities of the mutual correlation of signs in order to identify and assess the constitutional differences between patients with pyoderma and healthy people.

\section{Conclusions}

1. In healthy men of the Western regions of Ukraine, in the majority of cases lower values of the thickness of skin and fat folds than in patients with acute pyoderma and, separately, on the surface and deep, as well as chronic

\section{References}

[1] Alsterholm, M., Flytström, I., Bergbrant, I. M., Faergemann, J. (2010). Fusidic acid-resistant Staphylococcus aureus in impetigo contagiosa and secondarily infected atopic dermatitis. Acta Derm. Venereol., 90(1), 52-57. doi: 10.2340/ 00015555-0771.

[2] Brookheart, R. T., Michel, C. I., Schaffer, J. E. (2009). As a matter of fat. Cell. Metab., 10(1), 9-12. doi: 10.1016/ j.cmet.2009.03.011.

[3] Bunak, V. V. (1941). Anthropometry: a practical course. M.: Uchpedgiz. (3)

[4] Carter J. \& Heath B. (1990). Somatotyping - development and applications. Cambridge University Press.

[5] Chendogina, Y. O. (2009). The physical status of the skin disease of students, depending on the age and body type (PhD thesis). http://medical-diss.com.

[6] Cunnane, S. C., \& Crawford, M. A. (2003). Survival of the fattest: fat babies were the key to evolution of the large human brain. Comp. Biochem. Physiol. A. Mol. Integr. Physiol., 136(1), 17-26. https://www.ncbi.nlm.nih.gov/pubmed/ pyoderma are set; lower values of the endo- and mesomorph components of the somatotype and fatty component of the body mass, and larger values of the ectomorphic component of the somatotype, than in patients with acute course and, separately, superficial pyoderma. Also, healthy men have a lower percentage of endomesomorphic somatotype representatives than patients with deep pyoderma.

2. In healthy women, in most cases, smaller values of total (except for body length), most transverse, circumferential body sizes, width of distal epiphyses of long limb bones, as well as mesomorphic component of somatotype, muscle and bone components of body mass, and larger values of the ectomorphic component of the somatotype than those of the general group, patients with pyoderma and separately, on the surface and deep dermatosis are set. Also, in healthy women, a smaller percentage of the mesomorphic somatotype was found than in patients of the general group and with acute pyoderma; and a higher percentage of the representatives of the ectomorphic somatotype than patients with superficial pyoderma.

3. In patients with chronic pyoderma men, in the majority of cases, lower values of the transverse middle and lower thoracic dimensions and the thickness of skin and fat folds, endo- and mesomorphic components of the somatotype and bone and fat mass of the body are established, than in men patients with pyoderma and, separately, on the surface and deep.

4. In patients with chronic pyoderma in women, in most cases, smaller values of total, the majority of the circumcircle size of the limbs, half of the transverse pelvis size, the width of the distal epiphyses of the shoulder and thigh, muscle and bone components of the body mass, than those of patients with deep pyoderma, have been established. Also, patients with chronic pyoderma women have a higher percentage of representatives of the ectomorphic somatotype than patients with superficial pyoderma.

14527626 .

[7] Demidowich, A. P., Freeman, A. F., Kuhns, D. B., Aksentijevich, I., Gallin, J. I., Turner, M. L., ... Holland, S. M. (2013). Genotype, Phenotype, and Clinical Course in Five Patients With PAPA Syndrome (Pyogenic Sterile Arthritis, Pyoderma Gangrenosum, and Acne). Arthritis Rheum, 64(6), 20222027. doi: $10.1002 /$ art.34332.

[8] Edmonds, A. (2008). Beauty and health: Anthropological perspectives. Medische antropologie, 20(1), 151-162. http:// tma.socsci.uva.nl/20 1/edmonds.pdf.

[9] Heymsfield, S. B. (1982). Anthropometric measurement of muscle mass: revised eyuatiens for calculating bone-free arm muscle area. Am. J. Clin. Nutz., 36(4), 680-690. https:// www.ncbi.nlm.nih.gov/pubmed/7124671.

[10] Hoyt, L. T., \& Falconi, A. (2015). Puberty and Perimenopause: Reproductive Transitions and their Implications for Women's Health. Soc. Sci. Med., 132, 103-112. doi: 10.1016/ j.socscimed.2015.03.031.

[11] Joralemon, D. (2017). Exploring medical anthropology. The 
Global Petri Dish: Taylor \& Francis. https:// www.taylorfrancis.com/books/9781317348443.

[12] Layton, A. M., Thiboutot, D., Berson, D., Kang, S., Perez, M. (2014). Large-scale international study enhances understanding of skin disease dependent from somatotype: adult person. Eur. Acad. Dermatol. Venereol. , 2, 127-128. https://doi.org/10.1111/jdv.12757.

[13] Lepoutre, A., Doloy, A., Bidet, P., Leblond, A., Perrocheau, A., Bingen, E., ... Lévy-Bruhl, D. (2011). Epidemiology of invasive Streptococcus pyogenes infections in France in 2007. J. Clin. Microbiol. , 49(12), 4094-4100. doi: 10.1128/JCM.00070-11.

[14] Luca-Harari, B., Darenberg, J., Neal, S., Siljander, T., Strakova, L., Tanna, A., ... Jasir, A. (2009). Clinical and microbiological characteristics of severe Streptococcus pyogenes disease in Europe. J. Clin. Microbiol., 47(4), 1155-1165. doi: 10.1128/ JCM.02155-08.

[15] Lynskey, N. N., Lawrenson, R. A., Sriskandan, S. (2011). New understandings in Streptococcus pyogenes. Curr. Opin . Infect. Dis., 24(3), 196-202. doi: 10.1097/ QCO.0b013e3283458f7e.

[16] Makarchuk, I. M. (2014). Comparison of transverse body sizes between healthy and acne patients boys and girls from Podillia, taking into account and without taking into account the somatotype. Reports of Morphology, 20(2), 482-488.

[17] Makarchuk, I. M. (2014). Differences between total and longitudinal body sizes between healthy and boys and girls with acne, taking into account and excluding the somatotype. Biomedical and Biosocial anthropology, 23, 44-48.

[18] Marzano, A. V., Fanoni, D., Antiga, E., Quaglino, P., Caproni, M., Crosti, C., ... Cugno, M. (2014). Expression of cytokines, chemokines and other effector molecules in two prototypic autoinflammatory skin diseases, pyoderma gangrenosum and Sweet's syndrome. Clin. and Experim. Immunol., 178, 1, 4850. doi: 10.1111/cei.12394.

[19] Matiegka J. (1921). The testing of physical efficiency. Amer. J. Phys. Antropol., 2(3), 25-38.

[20] Nazarova, Y. V., Nazarov, N. O., Muilik, A. B. (2015). Individual specificity of the manifestation of adaptive qualities of the organism in women in the dynamics of the ovarian-menstrual cycle. Applied Information Aspects of Medicine, 18, 1, 130-135.

[21] Novotny, F., Bagnaschi, P., Kolpakov, V. V. (2009). The concept of typological variability of dermatological individuality: Somatotype heterogeneity of population groups differing in habitual physical activity. Medline from PubMed., 35, 6673.

[22] Ohtsuka, M., \& Yamamoto, T. (2014). Rare association of pyoderma gangrenosum and palmoplantar pustulosis: a case report and review of the previous works. J. Dermatol. , 41(8), 732-735. doi: 10.1111/1346-8138.12543.

[23] Rodin, A. Y., \& Proskuryakova, N. A. (2013). Perspectives of somatic research in dermatological practice. The article is presented in the materials of the conference "Sexually Transmitted Infections and Reproductive Health. Modern methods of diagnosis and treatment of dermatoses", Kazan ( $p$. 127-129). Kazan: Publishing house of KGMU. http:// www.unhcr.org/3bb822174.pdf

[24] Shklyar, A. S. (2013). Bone component of human body mass: anthropometric evaluation in the stages of postnatal ontogenesis (Methodological, innovative and applied aspects). Bulletin of Biology and Medicine problems, 4(2), 231-237.

[25] Shklyar, A. S. (2013). Muscular component of human body mass: anthropometric evaluation in the stages of postnatal ontogenesis (Methodological, innovative and applied aspects). Problems of ecological and medical genetics and clinical immunology, 5(119), 44-52.

[26] Shklyar, A. S. (2014). Fat component of human body mass: anthropometric evaluation in the stages of postnatal ontogenesis (Methodological, Innovative and Applied Aspects). Problems of ecological and medical genetics and clinical immunology, 1(121), 34-44. https://cyberleninka.ru/article/n/estimationmethods-and-rate-of-ontogenetically-disharmonic-bonecomponent-of-human-body-mass-in-various-age-andgender-groups.

[27] Skov, L., \& Baadsgaard, O. (2010). Bacterial superantigens and inflammatory skin diseases. Clin. Exp. Dermatol., 25, 57-61. https://www.ncbi.nlm.nih.gov/pubmed/10671976.

[28] Skripkin, Y. K., \& Butov, Y. S. (2009). Clinical dermatovenereology: a guide. In 2 volumes. M.: GEOTARMedia. http://mzdnr.ru/download/file/fid/10578.

[29] Stellmach, D., Beshar, I., Bedford, J., du Cros, P., Stringer, B. (2018). Anthropology in public health emergencies: what is anthropology good for? BMJ Glob. Health., 3(2), 1-7.

[30] Sweeting, H. N. (2007). Measurement and definitions of obesity in childhood and adolescence: a field guide for the uninitiated. Nutr. J., 6, 32-39. https://doi.org/10.1186/1475-2891-632.

[31] Vartanova, O. T. (2012). Characteristic expression of fatty body weight in men with psoriasis: a scientific publication. Journal of Anatomy and Histopathology, 1(2), 55-56. https:/ / www. researchgate.net/publication / 287526272_Psoriasis_and_diet.

[32] Vashchenko, Y. V. (2008). Clinical significance of evaluation of the functional activity of leukocytes in patients with chronic recurrent pyoderma (PhD thesis). http://medical-diss.com.

[33] Whitehall, J., Kuzulugil, D., Sheldrick, A., Wood, A. (2013). Burden of paediatric pyoderma and scabies in North West Queensland. J. Paediatr. and Child. Health, 49(2), 141-143. doi: 10.1111/jpc. 12095.

[34] Zouboulis, C.C., Stratakis, C.A., Chrousos, G.P., Koch, C.A. (2016). Metabolism and skin diseases. Rev. Endocr. and Metab. Disord. , 17(3), 241-246. https://link.springer.com/ article/10.1007/s11154-016-9396-6.

Матешук-Вацеба Л.Р., Чаплик-Чижо І.О.

\section{НАЙБІЛЬШ ВИРАЖЕНІ КОНСТИТУЦІОНАЛЬНІ РОЗБІЖНОСТІ МІЖ ЗДОРОВИМИ І ХВОРИМИ НА}

\section{ПІОДЕРМІЇ ЧОЛОВІКАМИ АБО ЖІНКАМИ ЗАХІДНОГО РЕГІОНУ УКРАЇНИ}

Незважаючи на значні успіхи, досягнуті у вивченні проблеми піодермій, питання клінічних особливостей їх перебігу залежно від соматотипу та їх відмінностей порівняно із здоровими досліджуваними залишаються практично не вивченими. Мета дослідження - встановлення найбільш виражених розбіжностей антропометричних, соматотипологічних і показників компонентного складу маси тіла у чоловіків і жінок Західного регіону України в нормі та хворих на піодермії. Проведено антропологічне обстеження згідно схеми Бунака 45 хворих на піодермії чоловіків віком від 22 до 35 років, та 48 хворих на піодермії жінок віком від 21 до 35 років, а також 24 практично здорових чоловіків та 43 практично здорових жінок аналогічного віку, у третьому поколінні мешканців Західного регіону України. Соматотип визначено згідно математичної схеми Хіт-Картера. Для обрахування жирового, кісткового та м'язового компонентів маси тіла використовували формули Маtiegka та 
Американського інституту харчування. За допомогою ліцензійного пакету "STATISTICA 6.0" виконано статистичну обробку отриманих результатів із застосуванням параметричних та непараметричних методів оцінки. У здорових чоловіків встановлено менші значення товщини шкірно-жирових складок, ніж у хворих на гострі і хронічні піодермії; а також менші значення ендой мезоморфного компонентів соматотипу та жирового компоненту маси тіла та більші значення ектоморфного компоненту соматотипу, ніж у хворих на гострий перебіг захворювання; менший відсоток представників ендо-мезоморфного соматотипу, ніж у хворих на глибокі піодермії. У здорових жінок встановлено менші, ніж у хворих жінок різних груп більшості тотальних, поперечних, обхватних розмірів тіла, ширини дистальних епіфізів довгих трубчастих кісток кінцівок, а також мезоморфного компоненту соматотипу, м'язового та кісткового компонентів маси тіла, а також більші значення ектоморфного компоненту соматотипу; менший відсоток представниць мезоморфного соматотипу, ніж у хворих загальної групи та з гострим перебігом піодермій, а також більший відсоток представниць ектоморфного соматотипу, ніж у хворих на поверхневі піодермії. Ухворих на хронічні піодермії чоловіків встановлено менші, ніж у хворих на гості піодермії чоловіків, значення поперечних середньота нижньогруднинного розмірів, товщини шкірно-жирових складок, ендо- $і$ мезоморфного компонентів соматотипу та кісткового i жирового компонентів маси тіла. У хворих на хронічні піодермії жінок встановлено менші, ніж у жінок хворих на глибокі піодермії, значення тотальних, половини поперечних розмірів таза, більшості обхватних розмірів кінцівок, ширини дистальних епіфізів плеча та стегна, м'язового та кісткового компонентів маси тіла, а також більший відсоток представниць ектоморфного соматотипу, ніж ухворих на поверхневі піодермії. Порівняльне дослідження антропометричних та соматотипологічних показників окремих статевих груп і конституціональних типів виявило індивідуальну мінливість структури тіла і встановило типологічні особливості пацієнтів з окремими формами і ступенем прояву піодермій.

Ключові слова: антропометрія, соматотип, компонентний склад маси тіла, практично здорові чоловіки і жінки Західного регіону, хворі на піодермії.

\section{Матешук-Вацеба Л.Р., Чаплик-Чижо И.О. НАИБОЛЕЕ ВЫРАЖЕННЫЕ КОНСТИТУЦИОНАЛЬНЫЕ РАСХОЖДЕНИЯ МЕЖДУ ЗДОРОВЫМИ И БОЛЬНЫМИ ПИОДЕРМИЯМИ МУЖЧИНАМИ ИЛИ ЖЕНЩИНАМИ ЗАПАДНОГО РЕГИОНА УКРАИНЫ}

Несмотря на значительные успехи, достигнутые в изучении проблемы пиодермий, вопрос клинических особенностей их течения в зависимости от соматотипа и их различий по сравнению со здоровыми испытуемыми остаются практически не изученными. Цель исследования - установление наиболее выраженных различий антропометрических, соматотипологических и показателей компонентного состава массы тела у мужчин и женщин Западного региона Украины в норме и больных пиодермиями. Проведено антропологическое обследование согласно схеме Бунака 45 больных пиодермиями мужчин в возрасте от 22 до 35 лет, и 48 больных пиодермиями женщин в возрасте от 21 до 35 лет, а также 24 практически здоровых мужчин и 43 практически здоровых женщин аналогичного возраста, в третьем поколении жителей Западного региона Украины. Соматотип определено согласно математической схеме Хит-Картера. Для расчета жирового, костного и мышечного компонентов массы тела использовали формулы Matiegka и Американского института питания. C помощью лицензионного пакета "STATISTICA 6.0" выполнено статистическую обработку полученных результатов $C$ применением параметрических и непараметрических методов оценки. У здоровых мужчин установлены меньшие значения толщины кожно-жировых складок, чем у больных острыми и хроническими пиодермиями; а также меньшие значения эндо- и мезоморфного компонентов соматотипа и жирового компонента массы тела и большие значения эктоморфного компонента соматотипа, чем у больных острым течением заболевания; меньший процент представителей эндомезоморфного соматотипа, чем у больных глубокими пиодермиями. У здоровых женщин установлено меньше, чем у больных женщин различных групп большинства тотальных, поперечных, обхватных размеров тела, ширины дистальных эпифизов длинных трубчатых костей конечностей, а также мезоморфного компонента соматотипа, мышечного и костного компонентов массы тела, а также большие значения эктоморфного компонента соматотипа; меньший процент представительниц мезоморфного соматотипа, чем у больных общей группы и с острым течением пиодермий, а также больший процент представительниц эктоморфного соматотипа, чем у больных поверхностными пиодермиями. У больных хроническими пиодермиями мужчин установлены меньше, чем у больных острыми пиодермиями мужчин, значения поперечных средне- и нижнегруднинного размеров, толщины кожно-жировых складок, эндо- и мезоморфного компонентов соматотипа и костного и жирового компонентов массы тела. У больных хроническими пиодермиями женщин установлено меньше, чем у женщин больных глубокиими пиодермиями, значение тотальных, половины поперечных размеров таза, большинства обхватных размеров конечностей, ширины дистальных эпифизов плеча и бедра, мышечного и костного компонентов массы тела, а также больший процент представительниц эктоморфного соматотипа, чем у больных поверхностными пиодермиями. Сравнительное исследование антропометрических и соматотипологических показателей отдельных половых групп и конституциональных типов выявило индивидуальную изменчивость структуры тела и установило типологические особенности пациентов с отдельными формами и степенью проявления пиодермий.

Ключевые слова: антропометрия, соматотип, компонентный состав массы тела, практически здоровые мужчины и женщины Западного региона, больные пиодермиями. 